\title{
Twentieth Anniversary of Leptin discovery and the Approval of Myalept by FDA
}

Ata Mahmoodpoor ${ }^{1}$, Javad Mahmoudi ${ }^{2}$, Saeed Sadigh-Eteghad ${ }^{2}$, Babak Sabermarouf ${ }^{2 *}$, Samad EJ Golzari ${ }^{3}$

1. Cardiovascular Research Center, Tabriz University of Medical Sciences, Tabriz, Iran

2. Neurosciences Research Center (NSRC), Tabriz University of Medical Sciences, Tabriz, Iran

3. Medical Education Research Center, Tabriz University of Medical Sciences, Tabriz, Iran

Leptin is a $16 \mathrm{kDa}$ hormone that is mainly expressed in adipose tissues (1). The major target of leptin is hypothalamus and it suppresses food intake and energy consumption, consequently diminishing adipose deposits and body weight $(2,3)$. The OB gene was isolated by Friedman in 1994 (4). Based on the suggestion of Roger Guillemin, Friedman named this new hormone "leptin" from the Greek lepto meaning thin $(5,6)$.

Since leptin discovery, numerous studies have been conducted on its physiological effects and its function in pathological conditions. Most of studies on leptin concentrated on its metabolic actions (7), receptors (8) and further broad functions such as immunity modulation (9) and memory processing (10). Considering such a vast range of functions, it is clear that patients with lack of leptin physiologically need pharmacological interventions.

At this moment, we are in the twentieth year of leptin discovery. Finally, FDA approved a drug named Myalept (metreleptin for injection) on February 2014 to treat rare metabolic disease caused by leptin deficiency.
Congenital generalized lipodystrophy is a disorder with partial lack of fat tissues (11). The trial for the safety and effectiveness of Myalept demonstrated decrease in $\mathrm{HbA1c}$, fasting blood glucose, and triglycerides (11). Nevertheless, there are some limitations to the usage of Myalept in HIV-related lipodystrophy and some metabolic disorders (11). Moreover, it may increase the risk of lymphoma by producing anti-metreleptin antibodies neutralizing endogenous leptin.

Considering these concerns, Myalept is available only through a limited profile under a Risk Evaluation and Mitigation Strategy (REMS). Myalept is contraindicated in patients with general obesity not related to congenital leptin deficiency (12).

Even though, Myalept has very limited indications for use in general population, it is considered a milestone towards the discovery of novel treatments for Leptin deficiencies and disorders.

Future investigations are necessary for the discovery of unknown aspects of Myalept therapy and production of new leptin-based

\section{Corresponding author:}

Babak Sabermarouf

Neurosciences Research Center (NSRC), Imam Reza Medical Center, Tabriz University of Medical Sciences, Gholghasht street, Azadi avenue, Tabriz, Iran, Postal code: 5166614756

Phone: +989143157278 Fax: +984133340730 Email: babak_sm@yahoo.com

Receive date: 2014-08-17| Accept date: 2014-09-01| Publish date: 2014-09-21

DOI: 10.7575/aiac.abcmed.15.03.02.09 
agents for treatment of a wide spectrum of

Keywords: Leptin; Myalept; Obesity; diseases.

\section{References}

1. Friedman JM, Halaas JL. Leptin and the regulation of body weight in mammals. Nature. 1998 Oct 22;395(6704):763-70. PubMed PMID: 9796811.

2. Chiba T, Shinozaki S, Nakazawa T, Kawakami A, Ai M, Kaneko E, et al. Leptin deficiency suppresses progression of atherosclerosis in apoE-deficient mice. Atherosclerosis. 2008 Jan;196(1):68-75. PubMed PMID: 17362969.

3. Friedman J. 20 years of leptin: leptin at 20: an overview. The Journal of endocrinology. 2014 Oct;223(1):T1-8. PubMed PMID: 25121999.

4. Zhang Y, Proenca R, Maffei M, Barone M, Leopold L, Friedman JM. Positional cloning of the mouse obese gene and its human homologue. Nature. 1994 Dec 1;372(6505):425-32. PubMed PMID: 7984236.

5. Leibel RL, Bahary N, Friedman JM. Genetic variation and nutrition in obesity: approaches to the molecular genetics of obesity. World review of nutrition and dietetics. 1990;63:90-101. PubMed PMID: 1973864.

6. Neill US. Leaping for leptin: the 2010 Albert Lasker Basic Medical Research Award goes to Douglas Coleman and Jeffrey M. Friedman. The Journal of Clinical Investigation. 2010;120(10):3413-8.

7. Farooqi IS, Matarese G, Lord GM, Keogh JM, Lawrence E, Agwu C, et al. Beneficial effects of leptin on obesity, T cell hyporesponsiveness, and neuroendocrine/metabolic dysfunction of human congenital leptin deficiency. J Clin Invest. 2002 Oct;110(8):1093-103. PubMed PMID: 12393845. Pubmed Central PMCID: 150795.

8. Tartaglia LA, Dembski M, Weng X, Deng N, Culpepper J, Devos R, et al. Identification and expression cloning of a leptin receptor, OB-R. Cell. 1995 Dec 29;83(7):1263-71. PubMed PMID: 8548812.

9. Lord GM, Matarese G, Howard JK, Baker RJ, Bloom SR, Lechler RI. Leptin modulates the T-cell immune response and reverses starvation-induced immunosuppression. Nature. 1998 Aug 27;394(6696):897-901. PubMed PMID: 9732873.

10. Farr SA, Banks WA, Morley JE. Effects of leptin on memory processing. Peptides. 2006 Jun;27(6):1420-5. PubMed PMID: 16293343.

11. FDA approves Myalept to treat rare metabolic disease: FDA; 2014. Available from: http://www.fda.gov/newsevents/newsroom/pressannouncements/ucm387060.htm. 12. myalept 2014. Available from: http://www.myalept.com/index.aspx. 